\title{
PENERAPAN MODEL E-COMMERCE UNTUK MENINGKATKAN PENJUALAN PRODUK KERAJINAN TANGAN
}

\author{
Turbudi ${ }^{1}$, Agus Umar Hamdani ${ }^{2 *}$ \\ ${ }^{1}$ Fakultas Teknologi Informasi, Sistem Informasi, Universitas Budi Luhur, Jakarta, Indonesia \\ ${ }^{2}$ Fakultas Teknologi Informasi, Sistem Informasi, Universitas Budi Luhur, Jakarta, Indonesia \\ Email: ${ }^{1}$ bagoezwiebowo@gmail.com, ${ }^{2 *}$ agus.umarhamdani@budiluhur.ac.id \\ (* : coressponding author)
}

\begin{abstract}
Abstrak - Toko XYZ merupakan industri rumah tangga yang menjual produk-produk kerajinan tangan (craft) di Kabupaten Pekalongan, Jawa Tengah. Saat ini, proses pengolahan data penjualan produk-produk kerajinan rumah tangga masih dilakukan secara manual, yaitu ditulis tangan ke dalam pembukuan. Proses pemesanan dilakukan menggunakan aplikasi Whatsaap atau harus datang langsung ke toko sehingga menyulitkan pelanggan yang berada di luar daerah. Selain itu, promosi produk juga dirasakan belum efektif, karena hanya dilakukan melalui Istagram dan Facebook. Selain itu, kondisi pandemic Covid-19 yang membatasi pergerakan warga menjadi salah satu penyebab menurunnya penjualan produk. Adapun masalah yang terjadi di Toko XYZ, antara lain : promosi produk yang tidak efektif, proses pemesanan membutuhkan waktu yang lama, pemilik mengalami kesulitan untuk melihat informasi status pembayaran, status pengiriman dan status penerimaan produk dari customer, dikarenakan harus melihat tracking info dan pemilik mengalami kesulitan untuk melihat informasi produk terlaris. Melihat kondisi diatas, maka penulis melakukan penelitian untuk menganalisa masalah dan membuat aplikasi penjualan secara elekronik (E-Commerce) guna membantu pemilik toko dalam mengatasi permasalahan diatas. Penulis menggunakan CMS Wordpress untuk implementasi sistem ECommerce dengan penambahan fitur pemasaran dan optimasi Search Engine Optimization (SEO). Hasil akhir dari penelitian ini adalah prototipe E-commerce yang dibangun dapat menunjang aktivitas penjualan dan pemasaran produk kerajinan tangan pada Toko XYZ.
\end{abstract}

Kata Kunci: E-Commerce, Kerajinan Tangan, CMS Wordpress, SEO

\begin{abstract}
XYZ shop is a home industry that sells handicraft products in Pekalongan Regency, Central Java. Currently, the process of processing sales data for household handicraft products is still done manually, which is handwritten into the books. The ordering process is carried out using the WhatsApp application or must come directly to the store, making it difficult for customers who are outside the area. In addition, product promotion is also felt to be ineffective, because it is only done through Instagram and Facebook. In addition, the Covid-19 pandemic, is one of the causes of the decrease in product sales. The problems that occur at the XYZ Store include: ineffective product promotions, the ordering process takes a long time, the owner has difficulty seeing payment status information, delivery status and product receipt status from customers, because they have to see tracking info and the owner experiences problems. difficult to see the best-selling product information. Seeing the above conditions, the authors conducted research to analyze the problem and create an electronic sales application (E-Commerce) to assist shop owners in overcoming the above problems. CMS Wordpress uses for the implementation of the E-Commerce system with the addition of marketing features and Search Engine Optimization (SEO). The final goal of this research is an E-commerce prototype that can support sales and marketing activities of handicraft products at the XYZ Store.
\end{abstract}

Keywords: E-Commerce, Craft, CMS Wordpress, SEO

\section{PENDAhuluan}

Saat ini, teknologi internet dimanfaatkan untuk mendukung kegiatan bisnis baik individu maupun perusahaan. Dengan adanya teknologi internet, maka transaksi yang sebelumnya dilakukan secara offline diubah menjadi transaksi yang dilakukan secara online. E-Commerce merupakan kegiatan menjual dan membeli produk menggunakan media internet. Selain itu, customer juga menggunakan internet sebagai sumber informasi untuk memilih harga terbaik yang diinginkan [1]. Beberapa penelitian terdahulu yang menjadi referensi penulis, antara lain : penelitian ke-1 [2] yang mengangkat masalah banyaknya UMKM yang belum menggunakan sarana teknologi informasi untuk mendukung usaha mereka dan diberikan solusi yang diberikan adalah penerapan E-Commerce menggunakan teknik SEO dan CMS untuk membantu pemasaran produk, penelitian ke-2 [3] yang membahas masih banyak UMKM yang belum memanfaatkan website untuk mendukung usaha sehingga diberikan solusi berupa penerapan E-Commerce dengan CMS dan SEO untuk memudahkan dalam mengelola penjualan dan pencarian produk, penelitian ke-3 [4] mengangkat masalah kurang efektifnya penggunaan perangkat teknologi informasi untuk mendukung penjualan produk aksesoris motor dan solusi yang diberikan berupa penerapan E-Commerce menggunakan CMS, penerapan teknik SEO dan strategi pemasaran 4P, penelitian ke-4 [5] mengangkat masalah belum adanya penggunakan teknologi informasi untuk mendukung meningkatkan penjualan sehingga diberikan solusi berupa penerapan E-Commerce dengan penerapan teknik SEO untuk mempermudah pencarian produk dan lokasi, penelitian ke-5 [6]. Toko XYZ merupakan industri rumah tangga yang menangani desain dan penjualan produk-produk kerajinan tangan (craft) di Kabupaten Pekalongan, Jawa Tengah. Saat ini, proses pengolahan data penjualan produk-produk kerajinan rumah tangga (craft) 
masih dilakukan secara manual, yaitu ditulis tangan ke dalam pembukuan. Proses pemesanan dilakukan menggunakan aplikasi Whatsaap atau pelanggan harus datang ke toko sehingga menyulitkan pelanggan yang berada di luar daerah. Selain itu, promosi produk juga dirasakan belum efektif, karena hanya dilakukan melalui media sosial, seperti Istagram dan Facebook. Selain itu, kondisi pandemi Covid-19 yang membatasi pergerakan warga menjadi salah satu penyebab menurunnya penjualan produk. Permasalahan yang dihadapi oleh Toko XYZ dijelaskan sebagai berikut: promosi produk tidak efektif, dikarenakan promosi nama toko dan produk hanya mengandalkan Istagram dan Facebook, proses pemesanan produk membutuhkan waktu yang lama, disebabkan pelanggan harus datang ke toko, pemilik mengalami kesulitan untuk merekam data pembayaran, dikarenakan harus dibuatkan nota secara manual, pemiljk mengalami kesulitan mengetahui informasi pengiriman produk, dikarenakan harus melihat informasi tracking info dari kurir, dan pemilik mengalami kesulitan untuk melihat informasi produk terlaris, dikarenakan harus merekapitulasi data penjualan terlebih dulu yang membutuhkan waktu yang lama. Berdasarkan latar belakang diatas dan merujuk pada studi literatur yang ada, maka penulis menawarkan solusi dengan membangun sistem E-Commerce guna meningkatkan penjualan produk-produk kerajinan tangan (craft) menggunakan teknologi E-Commerce. Adapun manfaat dari penelitian ini adalah website E-Commerce dapat digunakan untuk mempermudah transaksi penjualan dan memperluas area pemasaran.

\section{METODE PENELITIAN}

Penulis menggunakan penelitian terapan (Applied / Practical Research) sebagai pendekatan untuk memberikan solusi masalah yang terjadi di Toko XYZ, dimana penulis melakukan kajian pendahuluan untuk mengetahui kondisi yang terjadi saat ini, kemudian melakukan perbaikan sehingga hasilnya dapat bermanfaat untuk instansi riset [7]. Gambar 1 memperlihatkan urutan kegiatan yang penulis lakukan untuk menyelesaikan masalah.

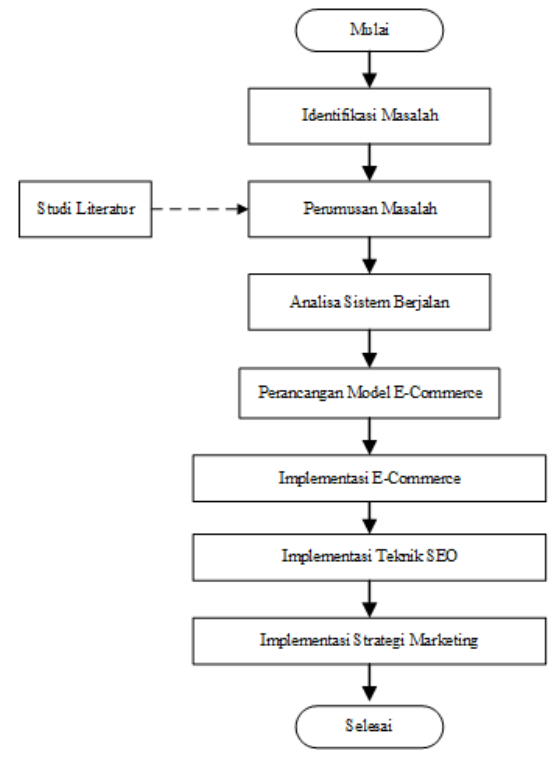

Gambar 1. Langkah-langkah Penelitian

Tahap awal melakukan identifikasi masalah di instansi riset, tahap kedua: melakukan kajian studi literatur, tahap ketiga : merumuskan masalah, yaitu menentukan solusi dari masalah yang diangkat, tahap keempat : melakukan analisa terhadap sistem berjalan, antara lain : analisa masalah menggunakan Fishbone Diagram, analisa model perencanaan bisnis dengan Business Model Canvas dan identifikasi kebutuhan sistem E-Commerce, tahap kelima : merancang sistem usulan dengan membuat desain rancangan layar, desain database dan desain input/output program, tahap keenam : implementasi sistem usulan dengan CMS Wordpress. Content Management System adalah perangkat lunak aplikasi untuk memanipulasi isi / konten sebuah website [8], serta dapat digunakan untuk mengatur konten website [9], tahap ketujuh : implementasi teknik SEO (Search Engine Optimization) yang bertujuan bertujuan untuk memperoleh posisi yang optimal di mesin pencari, serta mendapatkan pengunjung baru, tahap kedelapan : menerapkan strategi pemasaran untuk memperkenalkan produk kepada calon customer, tahap terakhir adalah melakukan pengujian kinerja teknik SEO dan penarikan kesimpulan dari hasil penelitian. 


\section{HASIL DAN PEMBAHASAN}

\subsection{Analisa Model Bisnis}

Business Model Canvas adalah konsep penggambaran secara visual mengenai bagaimana memahami, menilai dan mengganti model bisnis yang sesuai dengan kebutuhan bisnis sehingga dapat memberikan hasil kinerja bisnis yang optimal [10]. Komponen-komponen dalam Bussines Model Canvas meliputi : Value Propositions, merupakan nilai keunggulan bisnis yang dimiliki oleh Toko XYZ, yaitu produk diproduksi sendiri, memiliki logo produk / merek dagang, model produk dipesan oleh customer dan terdapat fitur pengembalian barang (return). Customer Segments, merupakan customer yang menjadi target pemasaran produk, yaitu : perorangan, penyelenggara acara nikahan / wisuda, rapat dan lain-lain, serta instansi / perusahaan. Channels, merupakan sarana yang digunakan Toko XYZ untuk menyampaikan atau menawarkan produknya, yaitu : Whatsapp, dan aplikasi E-Commerce. Customer Relationship, merupakan bagaimana cara menjalin hubungan yang baik dengan customer, yaitu : memberikan diskon, kupon dan souvenir. Key Partners, merupakan pihak yang menjadi mitra bisnis Toko XYZ, yaitu supplier bahan baku, distributor, penyedia jasa ekspedisi dan bank. Key Activities, merupakan kegiatan inti yang akan menghasilkan value proposition, yaitu : proses mendesain model produk, proses penjualan dan proses pemasaran produk. Key Resources, merupakan sumber daya utama yang dimiliki untuk menjalankan key activities, yaitu : desainer, admin penjualan, komputer, peralatan kerajinan. Cost Structure, biaya yang dikeluarkan untuk mendukung bisnis, yaitu : biaya gaji karyawan, biaya listrik, biaya internet dan telepon, biaya pengadaan bahan baku, biaya transportasi dan biaya operasional. Revenue Streams, sumber pendapatan yang dimiliki oleh Toko XYZ, yaitu hanya dari penjualan produk. Gambar 2 merupakan model bisnis usulan dari Toko XYZ.

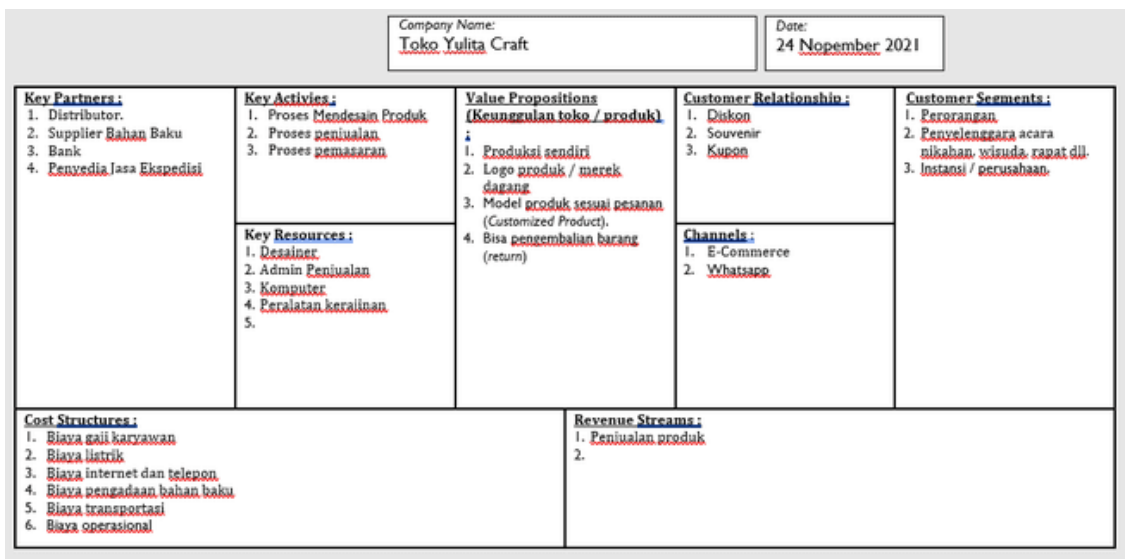

Gambar 2. Hasil Analisa Business Model Canvas

\subsection{Analisa Masalah}

Fishbone Diagram merupakan diagram berbentuk tulang ikan untuk menyelesaikan masalah dengan melakukan analisis terhadap hubungan sebab dan akibat yang ada pada sebuah masalah [11]. Gambar 3 merupakan penggambaran dari hasil analisis masalah permasalahan pada Toko XYZ.

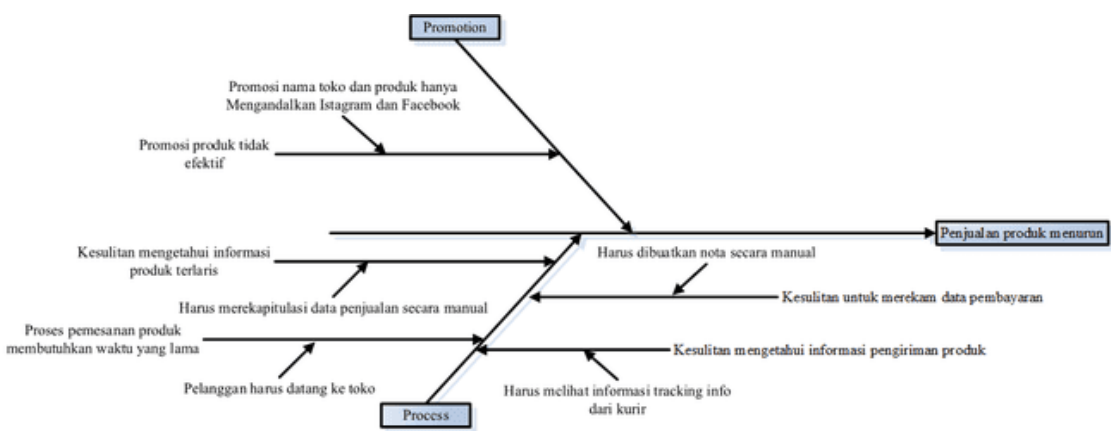

Gambar 3. Hasil Analisa Masalah dengan Fishbone Diagram

Adapun masalah yang terjadi dalam kategori proses, antara lain : a). proses pemesanan produk yang membutuhkan waktu yang lama, dikarenakan pelanggan harus datang ke toko, b). kesulitan untuk merekam data pembayaran, dikarenakan harus membuat nota secara manual, c). Kesulitan untuk mengetahui informasi pengiriman 
produk, dikarenakan harus melihat informasi tracking info dari kurir, d). Kesulitan mengetahui informasi produk terlaris, dikarenakan harus merekapitulasi data penjualan secara manual. Sedangkan untuk masalah yang terjadi pada kategori promosi, yaitu promosi produk tidak efektif, dikarenakan hanya mengandalkan Instagram dan Facebook. Tabel 1 merupakan penggambaran dari hasil identifikasi kebutuhan sistem usulan.

Tabel 1. Identifikasi Kebutuhan Sistem Usulan

\begin{tabular}{|c|c|c|c|}
\hline $\begin{array}{l}\text { Kategori } \\
\text { Masalah }\end{array}$ & $\begin{array}{c}\text { Uraian Masalah } \\
\text { (Problem Statement) }\end{array}$ & $\begin{array}{l}\text { Penxebab } \\
\text { (Causes) }\end{array}$ & $\begin{array}{c}\text { Identifikasi Kebutuhana Sistem } \\
\text { (Solusi Bisnis SI/TI) }\end{array}$ \\
\hline Promotion & $\begin{array}{l}\text { Promosi broduk tidak } \\
\text { effeltif. }\end{array}$ & $\begin{array}{lr} & \text { Promosi nama toks } \\
\text { dan produl } & \text { hanya } \\
\text { mengandalkan } & \text { Istagram } \\
\text { dan Facebook. } & \end{array}$ & $\begin{array}{l}\text { - Sistem harus menxediakan } \\
\text { fitur_promosi produk. } \\
\text { - Sistem harus menxediakan } \\
\text { fitur \&ptimasi mesin } \\
\text { Bencari. }\end{array}$ \\
\hline Process & $\begin{array}{l}\text { Proses pemesanan produlk } \\
\text { membutuhkan waktu yang } \\
\text { lama. }\end{array}$ & $\begin{array}{l}\text { Pelanggan } \\
\text { gatang ke tokse. }\end{array}$ & $\begin{array}{l}\text { - Sistem } \\
\text { fituc. p } \\
\text { online. }\end{array}$ \\
\hline Process & $\begin{array}{l}\text { Kesulitan untuk merekam } \\
\text { data pembayaran. }\end{array}$ & $\begin{array}{l}\text { Harus dibuatkan nota } \\
\text { secara manual. }\end{array}$ & $\begin{array}{l}\text { - Sisten } \\
\text { fitur B } \\
\text { stoma }\end{array}$ \\
\hline Proce & $\begin{array}{l}\text { Kesulitan } \\
\text { informasit } \\
\text { produk }\end{array}$ & \begin{tabular}{l}
\multicolumn{1}{c}{ Harus melihat } \\
informasi \\
dari kuckir.
\end{tabular} & $\begin{array}{l}\text { - Sistem harus menyedialkan } \\
\text { fitur untuk mengundate } \\
\text { dan melihat status } \\
\text { pengiriman. }\end{array}$ \\
\hline Process & $\begin{array}{l}\text { Pemilik mengalami kesulitan } \\
\text { yntuk melihat infermasi } \\
\text { produk terlaris }\end{array}$ & $\begin{array}{l}\text { Harus merekapitulasi } \\
\text { data penjualan terlebih } \\
\text { dulu yang membutuhkan } \\
\text { waktu yang lama. }\end{array}$ & $\begin{array}{l}\text { - Sistem harus menyediakan } \\
\text { fitur yntuk melihat } \\
\text { infermasi produk terlaris. }\end{array}$ \\
\hline
\end{tabular}

\subsection{Proses Bisnis}

Gambar 4 merupakan proses entry pesanan, pelanggan login, kemudian memilih produk yang akan dibeli dan menginput jumlah barang. Kemudian melakukan View Cart, memilih kurir dan melakukan Checkout. Kemudian sistem akan menampilkan total tagihan pembayaran dan mengirimkan notifikasi pesanan kepada customer. Pada gambar 5 merupakan proses upload bukti pembayaran, kemudian sistem menyimpan data pembayaran dan admin akan mengubah status pesanan. Kemudian sistem mengirimkan konfirmasi pesanan kepada customer.

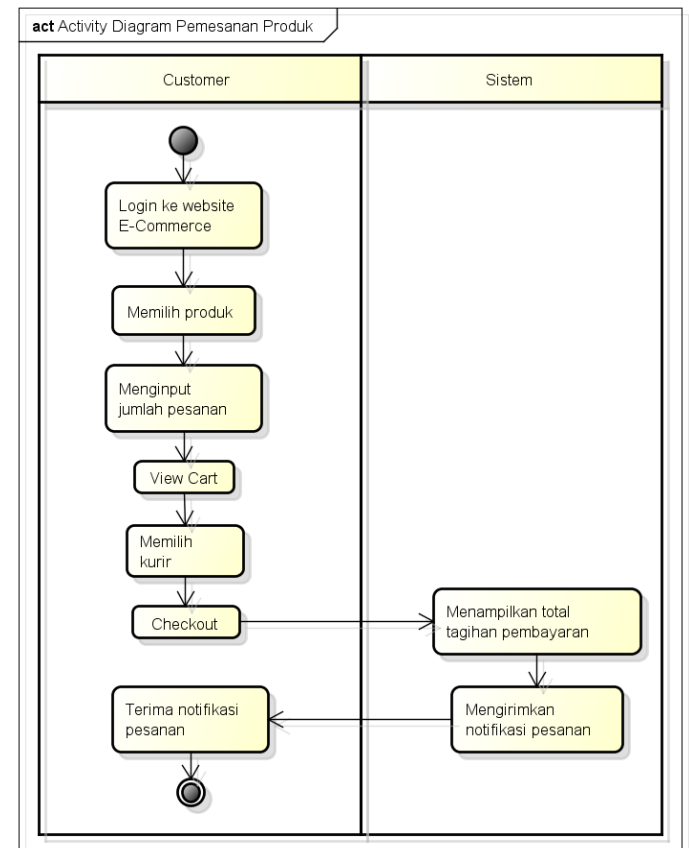

Gambar 4. Proses Pemesanan Produk

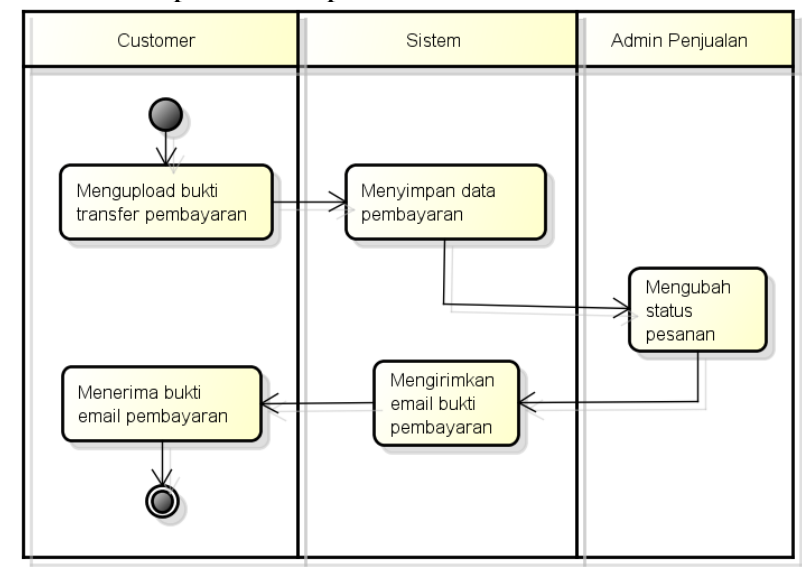

Gambar 5. Proses Upload Bukti Pembayaran

\subsection{Pemodelan Sistem}

Use case diagram merupakan kegiatan yang dilakukan oleh actor pada sistem [12]. Gambar 6 merupakan Use Diagram File Master, yang terdiri atas : entry produk, entry data kurir, entry data coupon dan entry data Discount yang dilakukan oleh aktor admin penjualan. 

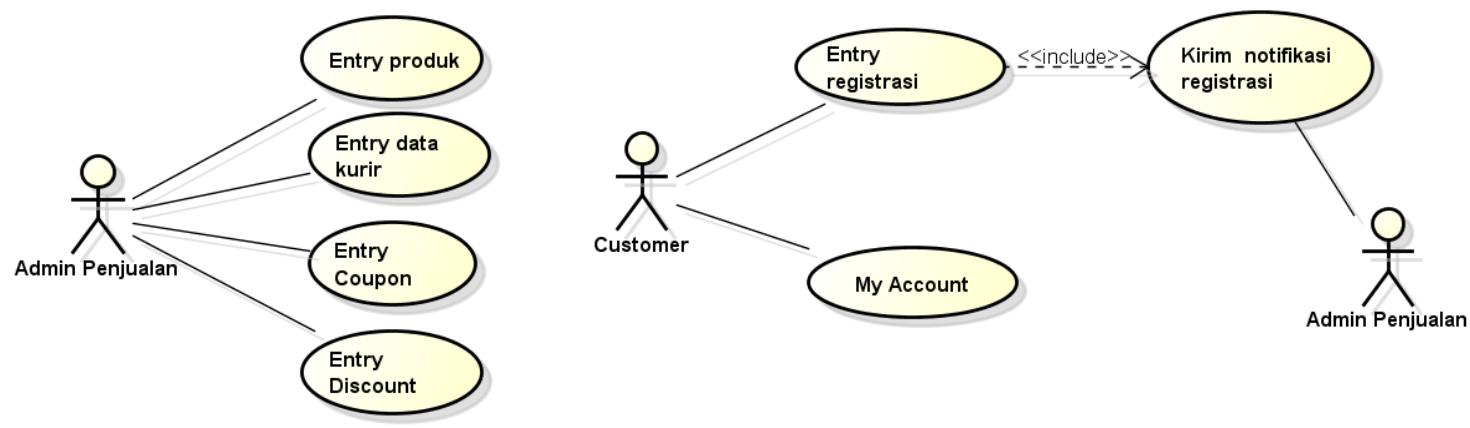

Gambar 6. Use Case Diagram File Master

Gambar 7 merupakan Use Case Diagram Transaksi disisi Front End yang terdiri atas : Entry \& View Cart, Checkout, Konfirmasi Pembayaran, Konfirmasi Penerimaan, dan Entry Ulasan, aktivitas tersebut dilakukan oleh Customer dan Admin Penjualan menerima notifikasi dari setiap transaksi oleh Customer. Sedangkan Use Case Diagram Transaksi disisi Back End terdiri atas : Update Status Pesanan, Update Status Ulasan, Promosi Produk dan Optimasi SEO, semua aktivitas tersebut dilakukan oleh Admin Penjualan dan Customer menerima notifikasi dari setiap transaksi yang dilakukan oleh Admin Penjualan.
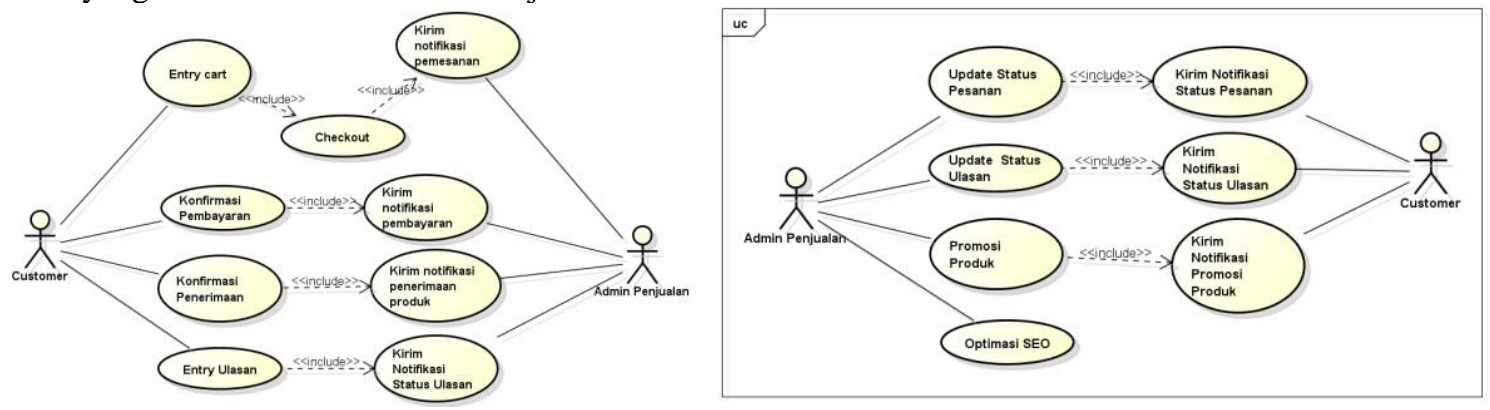

Gambar 7. Activity Diagram Transaksi

Gambar 8 merupakan Use Case Diagram Laporan yang terdiri atas : Cetak Laporan Penjualan, Cetak Laporan Pembayaran, Cetak Laporan Pengiriman, Cetak Laporan Penerimaan, Cetak Laporan Stok, Cetak Laporan Rekapitulasi Produk Terlaris dan Cetak Laporan Rekapitulasi Pendapatan yang dilakukan oleh Admin Penjualan dan Pemilik Toko.
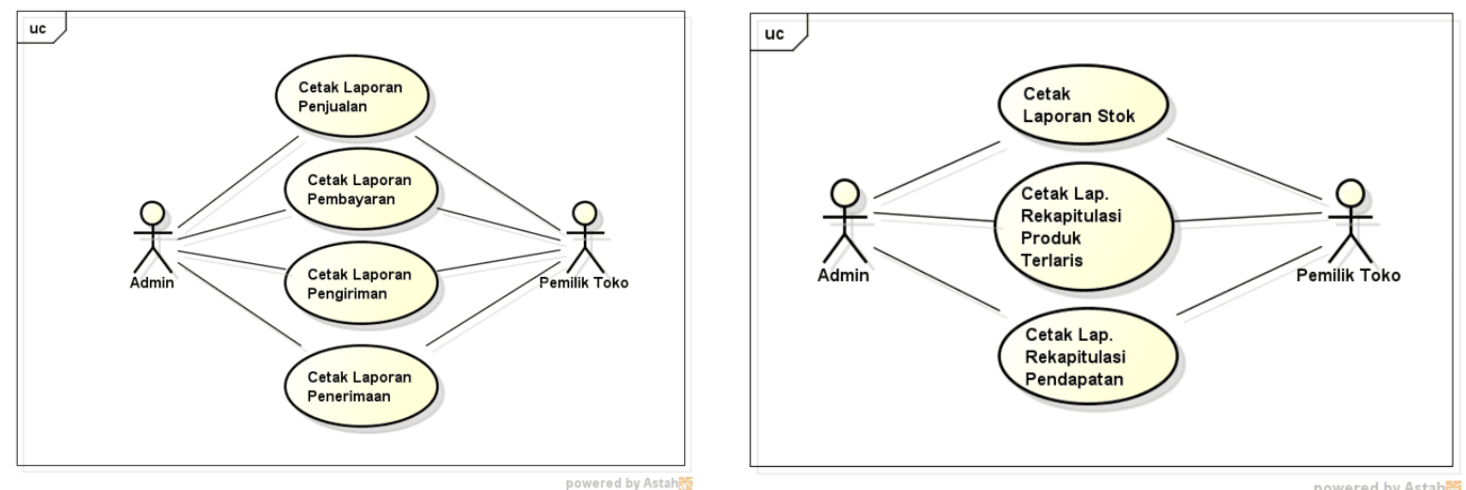

Gambar 8. Use Case Diagram Laporan

\subsection{Pemodelan Konseptual Data}

Class Diagram adalah diagram yang digunakan untuk memodelkan kumpulan class dan relasinya, serta aksi yang terjadi [12]. Gambar 9 merupakan penggambaran model class diagram dalam aplikasi E-Commerce usulan yang terdiri dari terdiri atas : WPOj_Users, WPOj_Post, WPOj_Term_Taxonomy, WPOj_Terms_Relationship, WPOj_Usermeta, WPOj_WC_Product_Meta_Lookup, WPOj_Terms, WPOj_Postmeta, WPOj_WooCommerce_Order_Items, WPOj_WooCommerce_Order_Itemmeta dan WPOj_Termmeta. 


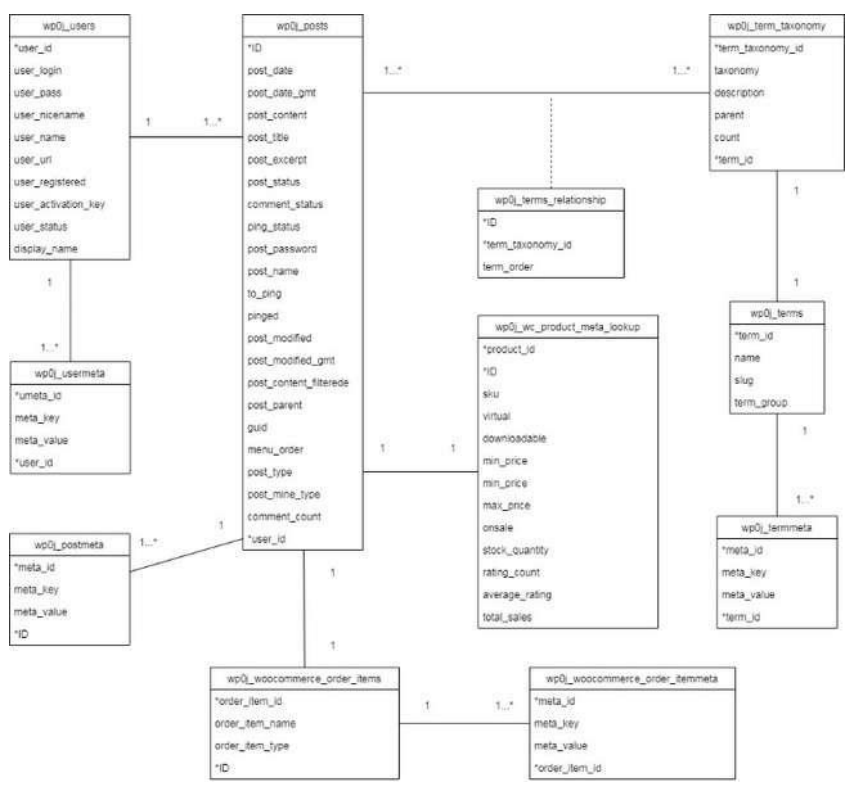

Gambar 9. Class Diagram

\subsection{Pemodelan Perilaku Sistem}

System Sequence Diagram adalah diagram untuk menampilkan interaksi yang terjadi antar obyek yang ada di dalam sistem [13]. Pada gambar 10 merupakan diagram yang menggambarkan perilaku system yang terjadi pada proses pemesanan produk.

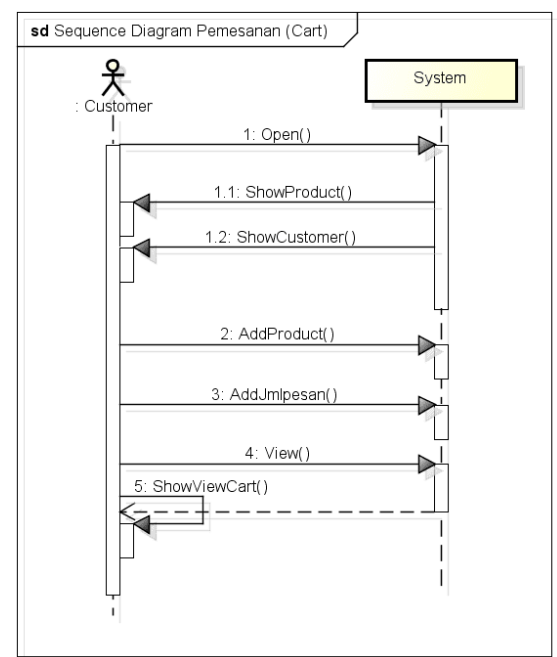

Gambar 10. System Sequnce Diagram Entry Pesanan

\subsection{Implementasi Sistem}

Pada gambar 11 merupakan tampilan awal halaman beranda dari website TOKO XYZ. Pada tampilan ini berisikan referensi produk-produk yang tersedia dan terdapat menu Register serta Login. 


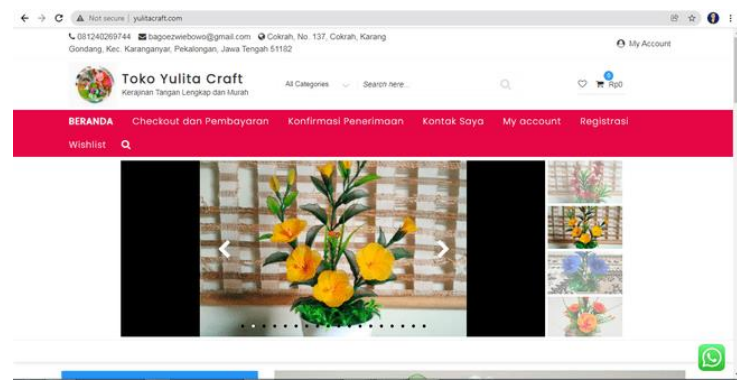

Gambar 11. Tampilan Halaman Awal

Gambar 12 merupakan halaman untuk menampilkan informasi pesanan dan jumlah tagihan pembayaran, kemudian customer melakukan proses Checkout. Pada saat tersebut, customer akan menerima notifikasi pemesanan melalui email.

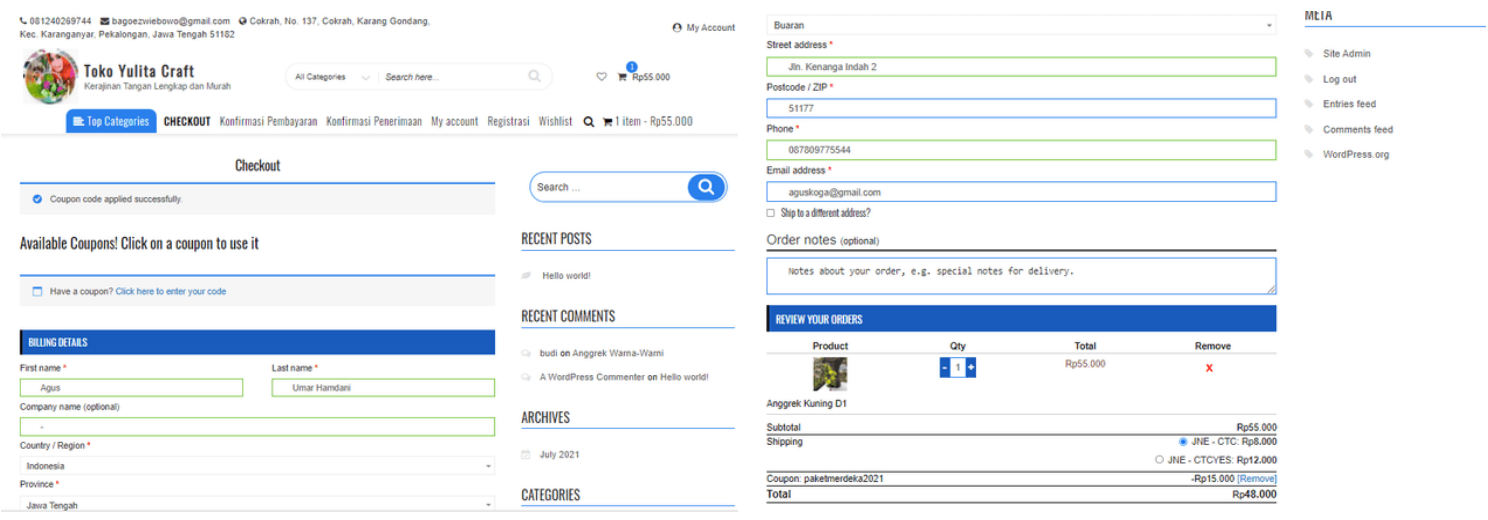

Gambar 12. Tampilan Halaman (Checkout)

Pada gambar 13 merupakan halaman untuk melakukan mengupload bukti pembayaran oleh customer. Kemudian customer akan menerima notifikasi pembayaran melalui email.
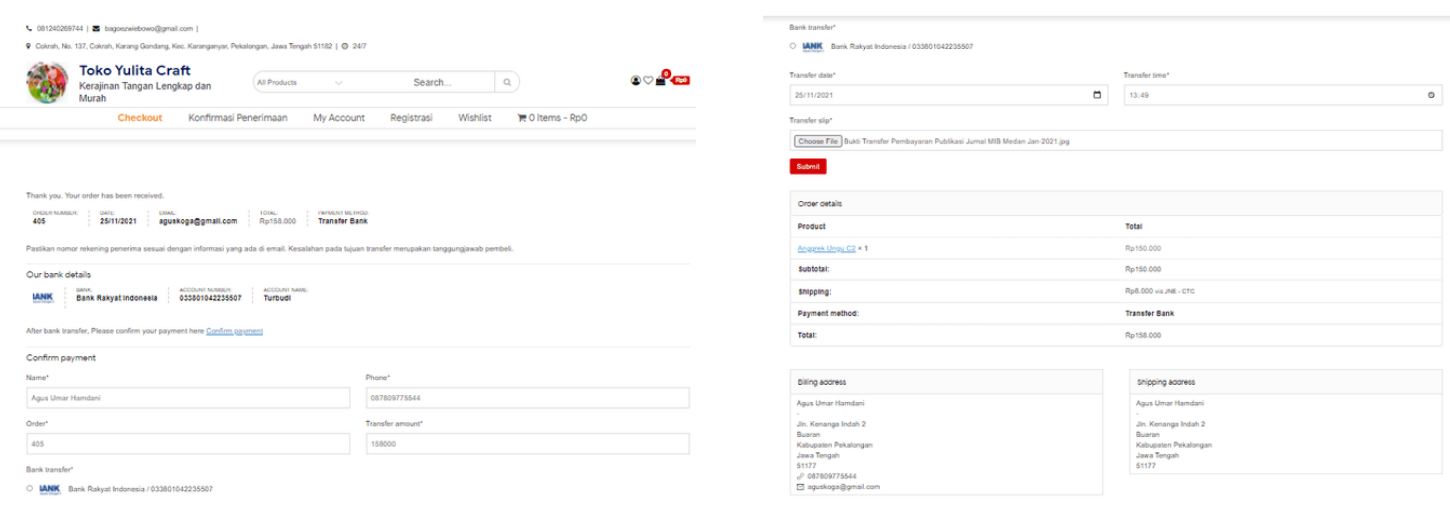

Gambar 13. Tampilan Konfirmasi Pembayaran

\subsection{Hasil Keluaran Program}

Pada gambar 14 merupakan keluaran laporan pemesanan produk yang dihasikan oleh aplikasi E-Commerce, yang berisi data product id, produk SKU, product name, quantity sold, gross sales, product categories dan gross sales. 


\begin{tabular}{|c|c|c|c|c|c|c|}
\hline Product io & Product SKU & Product Name & Quantity Sold & Gross Sales & Product Categories & Gross Sales (After Discounts) \\
\hline 70 & & Anggrek Ungu C2 & 5 & 660000 & Uncategorized & 648000 \\
\hline 59 & & Anggrek Merah A1 & 2 & 88000 & Uncaregorized & 84000 \\
\hline 44 & & Bunga Anggrek Merah & 1 & 60000 & Uncategorized & 60000 \\
\hline 73 & & Anggrek Kuning D1 & 1 & 45000 & Uncategorized & 45000 \\
\hline 46 & & Buket Wisuda & 1 & 95700 & Craft & 71775 \\
\hline
\end{tabular}

Gambar 14. Hasil Cetakan Laporan Pemesanan Produk

Berikut adalah hasil dari keluaran notifikasi yang diterima oleh admin dari pelanggan, tertera pada gambar 15 :

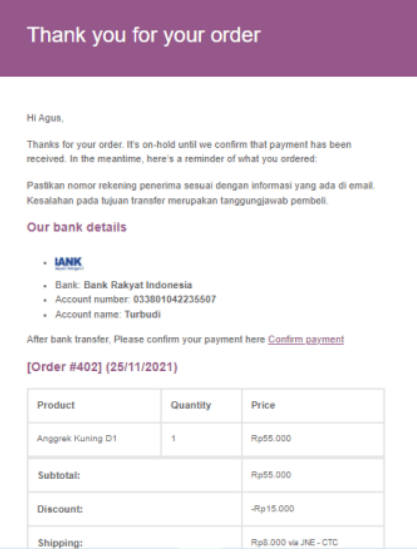

Gambar 15. Hasil Keluaran Notifikasi pada Halaman Admin

\subsection{Hasil Pengujian Kinerja Website E-Commerce}

Search Engine Optimization merupakan aktivitas untuk meningkatkan trafik kunjungan situs website melalui mesin pencari dengan menggunakan sistem algoritma kata kunci [14]. Berikut ini beberapa implementasi teknik optimasi SEO On Page yang dilakukan pada website www.yulitacraft.com.

a) Riset kata kunci

Dalam tahapan ini, peneliti melakukan penelitian kata kunci yang menjadi fokus pencarian. Penulis menggunakan Keyword Tools untuk membantu menemukan kata kunci yang tepat,. Gambar 16 merupakan proses penentuan kata kunci yang akan digunakan.

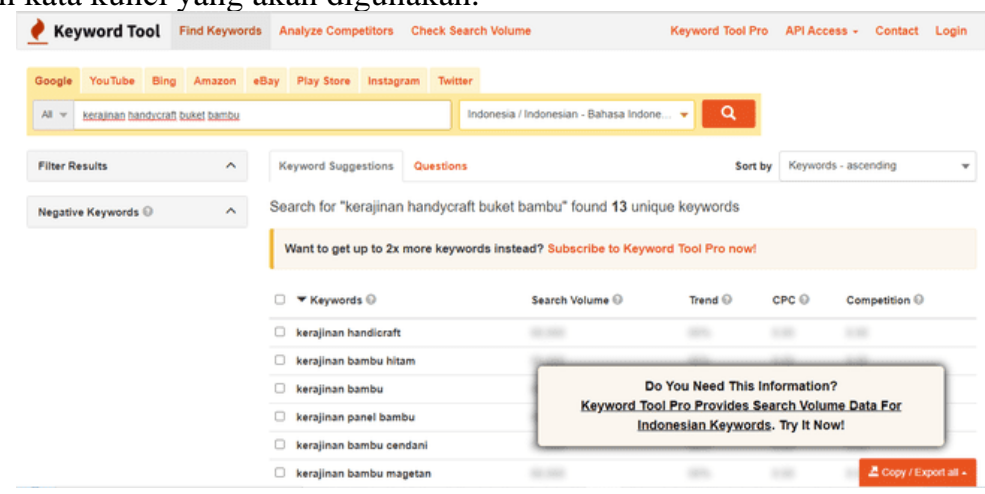

Gambar 16. Hasil Riset Kata Kunci

Berdasarkan hasil riset kata kunci diatas, maka peneliti mengambil kata yang terdiri atas : "kerajinan handycraft buket bambu".

b) Hasil Pengujian Kinerja Website E-Commerce

Gambar 17 merupakan hasil kinerja penelusuran web ke alamat URL www.yulitacraft.com selama 3 (tiga) bulan sejak 23 Agustus 2021 hingga 19 Nopember 2021 yang diperoleh data sebagai berikut : Total Click adalah jumlah pengunjung yang membuka alamat URL website sebanyak 1 pengunjung, Total 
Empressions $=$ jumlah orang yang melakukan pencarian terhadap kata kunci dan jumlah pengunjung yang membuka alamat URL website sebanyak 11 orang, Average CTR =9,1\% dan Average Position = 3,5

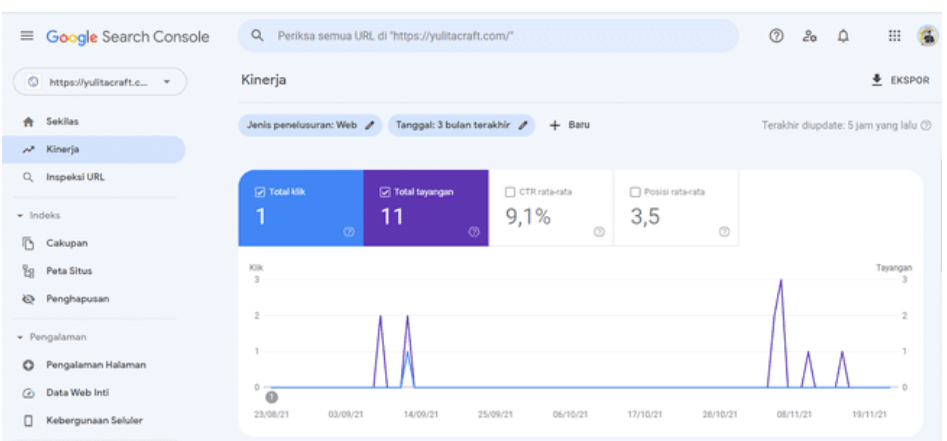

Gambar 17. Hasil Pengujian Kinerja Website E-Commerce

Setelah itu, untuk menguji keberhasilan teknik SEO, maka perlu dilakukan pencarian di mesin Google Search. Gambar 18 menjelaskan hasil pencarian kata kunci menggunakan kata kunci "kerajinan craft pekalongan yulita" dilakukan pada 26 Nopember 2021, pukul 10.05 WIB.

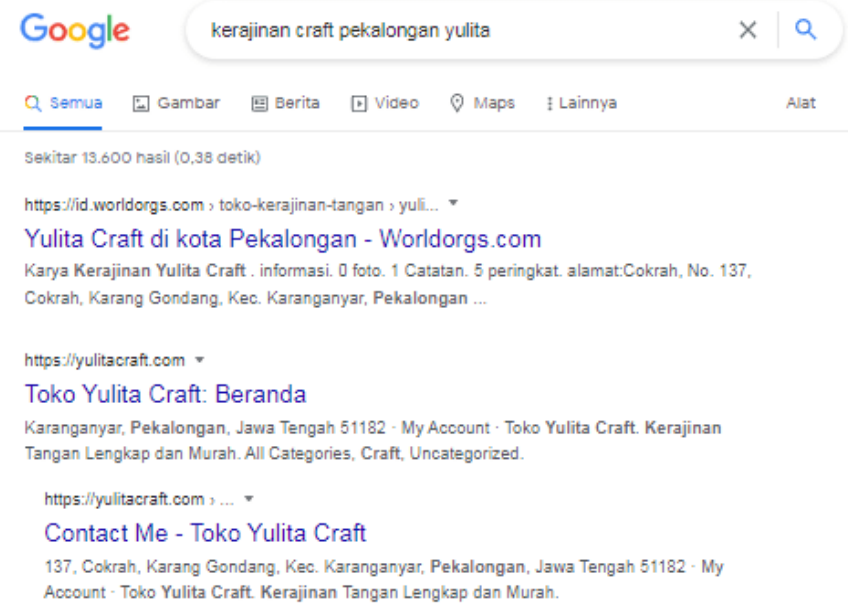

Gambar 18. Hasil Pengujian Pencarian Kata Kunci

\subsection{Strategi Pemasaran (Marketing)}

Strategi Pemasaran adalah serangkaian kegiatan untuk menentukan arah pada usaha-usaha pemasaran sehingga mampu memenangkan persaingan bisnis [15]. Adapun strategi pemasaran yang diusulkan oleh penulis untuk Toko XYZ dalam meningkatkan penjualan menggunakan strategi produk dan strategi harga.. Pada Tabel 2 merupakan strategi pemasaran pada Toko XYZ.

Tabel 2. Strategi Pemasaran

\begin{tabular}{|l|l|}
\hline \multicolumn{1}{|c|}{ Komponen Strategi Marketing } & \multicolumn{1}{c|}{ Strategi yang dilakukan } \\
\hline Product (Strategi Produk) & Membuat katalog produk. \\
\hline Price (Strategi Harga) & Memberikan diskon, kupon. \\
\hline
\end{tabular}

Gambar 19 merupakan implementasi strategi produk yang berupa katalog produk. Katalog produk berisi berbagai jenis produk yang dijual disertai dengan penjelasan mengenai produk tersebut. 


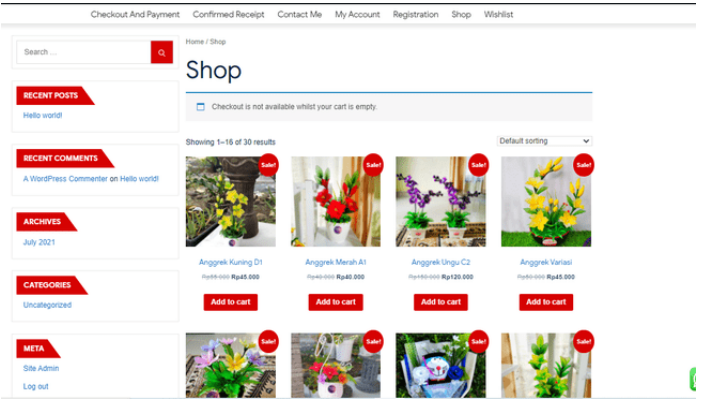

Gambar 19. Merupakan implementasi strategi produk

Gambar 20 merupakan implementasi strategi harga yang berupa kupon dan diskon. Pemberian kupon dan diskon tersebut memiliki batas waktu dan dapat diterapkan pada saat melakukan Checkout.

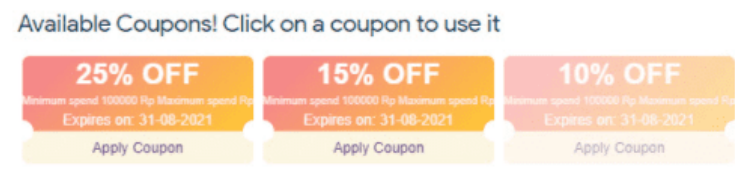

Discount upto $25 \%$, Limited time offer

Gambar 20. Strategi Price memberikan Kupon dan Diskon

\section{KESIMPULAN}

Berdasarkan hasil kajian berupa perancangan model E-Commerce pada Toko XYZ, maka dapat kesimpulan sebagai berikut : website E-Commerce dapat membantu pelanggan untuk berbelanjg menggunakan modul keranjang belanja (Shopping Cart) dan tidak perlu datang ke toko, mereka bisa memesan barang dimana pun dan kapan saja, informasi stok barang dapat dilihat secara langsung melalui modul katalog produk pada saat pemesanan atau laporan ketersediaan stok untuk admin, data penjualan yang tidak valid dapat ditangani dengan adanya modul checkout, payment, pengiriman barang dan penerimaan barang sehingga informasi penjualan menjadi lebih valid dan lengkap, modul laporan pemesanan, modul laporan pembayaran, modul laporan pengiriman barang dan laporan penerimaan barang dapat membuat dalam pembuatan laporan operasional menjadi lebih cepat dibandingkan dengan pembuatan laporan secara konvensional.

\section{DAFTAR PUSTAKA}

[1] A. G. Khan, "Electronic Commerce: A Study on Benefits and Challenges in an Emerging Economy," Glob. J. Manag. Bus. Res. Econ. Commer., vol. 16(1), 2016.

[2] D. A. Rizaldi, Taufiq., Arief P, Hermawan dan Tyagita, "Penerapan E-Commerce Berbasis SWO dan CMS Sebagai Solusi Pemasaran dan Manajemen Pada Industri Kreatif Bidang Robotika,” in Seminar Nasional Hasil Pengabdian Masyarakat dan Penelitian Pranata Laboratorium Pendidikan Politeknik Negeri Jember Tahun 2019, 2019.

[3] A. dan P. Sutanto, Felix Andreas., Supriyanto, "Penerapan E-Commerce Berbasis CMS dan SEO Untuk Toko Online UMKM," J. ABDIMAS, vol. 19(2), 2015.

[4] A. U. Riandika, Dedi dan Hamdani, "Implementasi E-Commerce Dengan Teknik SEO dan Strategi Marketing 4P Untuk Meningkatkan Penjualan Produk Aksesoris Motor Pada XYZ Motoshop," J. Media Inform. Budidarma., vol. 4(3), 2020.

[5] M. Pratomo, Adi., Najwaini, Effan., Irawan, Agus dan Risa, “Optimasi E-Commerce Dengan Penerapan Teknik SEO (Search Engine Optimization) Untuk Meningkatkan Penjualan Pada UMKM Nida Sasirangan,” J. IMPACT (Implementation Action), vol. 1(1), 2018.

[6] A. Himawan, Arisantoso, dan Saefullah, "Search Engine Optimization (SEO) Menggunakan Metode White Hat SEO Untuk Meningkatkan Peringkat dan Trafik Kunjungan Website," in Prosiding SNATIF-4 tahun 2017, 2017. 
[7] S. Anggara, NoMetode Penelitian Administrasi. Bandung: CV Pustaka Setia, 2015.

[8] Sarwandi, Toko Online Modern Dengan Opencart. Jakarta: PT. Elex Media Komputindo, 2016.

[9] R. Abdulloh, Trik Mudah Membuat CMS Website dari Nol. Jakarta: PT. Elex Media Komputindo, 2016.

[10] R. Indiany, N dan Indriyani, “Analisis Pengembangan Bisnis Dengan Pendekatan Business Model Canvas Pada UD. Mogajaya Surabaya,” vol. 5(2), 2017.

[11] D. A. Pramujaya, A.Vandy dan Kurniawai, “Analisis Penyebab Kegagalan Packer Machine Pada Bag Transfer System Dengan Menggunakan Metode Fault Tree Analysis (FTA), Failure Mode And Effect Analysis (FMEA), dan Fishbone Analysis," 2019.

[12] S. Mulyani, Metode Analisis dan Perancangan Sistem. Bandung: Abdi Sistematika, 2016.

[13] J. Nofriyadi, "Sequence Diagram Sebagi Perkakas Perancangan Antarmuka Pemakai," 2014.

[14] J. Venkat, N., Gudivada, Rao, D. dan Pari, "No Title," the IEEE Computer Society, 2015.

[15] S. Assauri, Manajemen Pemasaran. Jakarta: Rajawali Press, 2013. 